\title{
Analisis Kemampuan Koneksi Matematis Siswa SMP pada Materi Sistem Persamaan Linear Dua Variabel (SPLDV)
}

\author{
Agil Arif Nugraha \\ Pendidikan Matematika, STKIP Al Hikmah Surabaya \\ e-mail: agilarif41@gmail.com
}

\begin{abstract}
ABSTRAK. Penelitian ini bertujuan untuk mengetahui kemampuan koneksi matematis siswa SMP pada materi Sistem Persamaan Linear Dua Variabel (SPLDV). Metode penelitian yang digunakan adalah desain penelitian kualitatif. Sampel dalam penelitian ini adalah 3 siswa kelas VIII di salah satu sekolah negeri di Surabaya. Data dianalisis dengan menggunakan reduksi data, penyajian data, dan penarikan kesimpulan. Berdasarkan hasil penelitian dapat disimpulkan bahwasanya kemampuan koneksi matematis siswa SMP pada materi SPLDV masih rendah terutama dalam mengaplikasikan dalam kehidupan sehari-hari.
\end{abstract}

Kata kunci : Koneksi matemastis, siswa SMP, materi SPLDV.

\section{PENDAHULUAN}

Matematika adalah suatu ilmu yang terstruktur dan saling berkaitan antar satu topik dengan topik yang lain. sebagai ilmu yang saling memiliki keterkaitan, maka dalam menyelesaikan suatu masalah matematika, siswa harus memiliki koneksi matematis yang memadai.

Koneksi matematis merupakan salah satu kemampuan yang harus dimiliki oleh seorang siswa ketika belajar matematika di sekolah. Menurut Ruspiani (2000: 68), kemampuan koneksi adalah kemampuan mengaitkan konsep-konsep matematika baik antar topik dalam matematika itu sendiri maupun mengaitkan konsep matematika dengan konsep dalam bidang lainnya. Sementara menurut National Council of Teachers of Mathematics (NCTM: 2000:274), koneksi matematis adalah keterkaitan antar topik matematika dengan disiplin ilmu yang lain dan keterkaitan matematika dengan dunia nyata atau kehidupan sehari-hari. Menurut pemaparan dari Ruspiani dan NCTM dapat disimpulkan bahwa keterkaitan bukan sekedar keterkaitan antar konsep dalam matematika saja. Tetapi juga antara matematika dengan bidang ilmu yang lain dan matematika dengan kehidupan sehari-hari.

Kemampuan koneksi dalam matematika memegang peran penting dalam menyelesaikan masalah matematika. Dengan kemampuan tersebut, siswa dapat memahami masalah matematika secara detail. Namun menurut Mahmudah (2013), kemampuan koneksi matematis siswa di Indonesia masih tergolong rendah. Terutama pada penerapan antara konsep materi tertentu dengan materi yang lain dan penerapan materi matematika dengan bidang ilmu yang lain. sedangkan menurut Warih, dkk (2016), siswa tidak bisa menerapkan konsep yang telah dipelajari sebelumnya dengan konsep yang dipelajari berikutnya. Sehingga dalam hal ini, siswa kesulitan dalam memahami soal. Beberapa penelitian tersebut menunjukkan rendahnya kemampuan koneksi matematis siswa yang meliputi aspek koneksi matematis. Seperti contoh adalah pada pengaitan konsep antara Sistem 
Persamaan Linear Dua Variabel (SPLDV) dengan materi Persamaan Linear Dua Variabel (PLSV), operasi aljabar, Persamaan Linear Satu Variabel (PLSV), dan Persamaan garis lurus. Apabila siswa mampu mengaitkan ide-ide matematika tersebut, maka pemahaman matematikanya akan semakin dalam dan bertahan lama karena mereka mampu melihat keterkaitan antar topik matematika dengan topik di bidang yang lain dan kehidupan sehari-hari (NCTM, 2000:64). Sedangkan menurut Anandita (2015), indikator yang digunakan untuk menganalisis kemampuan koneksi matematis siswa SMP kelas VIII adalah sebagai berikut: (1) menemukan hubungan dari berbagai representasi tentang konsep dan prosedur matematika. (2) memahami hubungan antar topik dalam matematika. (3) mampu menggunakan matematika dalam penyelesaian masalah dalam kehidupan sehari-hari. (4) memahami representasi konsep yang ekuivalen. (5) menemukan hubungan antara prosedur satu dengan lainnya yang ekuivalen. (6) menggunakan koneksi antara matematika dengan matematika sendiri maupun dengan ilmu yang lain.

Berdasarkan uraian diatas, peneliti ingin menganalisis koneksi matematis siswa pada materi Sistem Persamaan Linear Dua Variabel (SPLDV). Koneksi matematis dalam penelitian ini adalah hubungan konsep atau prosedur matematika dalam satu topik yang sama dan hubungan antara konsep dalam suatu konsep dengan topik yang lain. Indikator untuk mengetahui koneksi matematis siswa yang digunakan dalam penelitian ini adalah mengetahui hubungan antara ide-ide matematis (konsep atau prosedur), menggunakan hubungan antara ide-ide matematis (konsep atau prosedur), dan menghubungkan ide-ide matematis (konsep atau prosedur). Rumusan masalah dalam penelitian ini adalah bagaimana koneksi matematis siswa SMP dalam menyelesaikan masalah Sistem Persamaan Linear Dua Variabel (SPLDV). Dipilihnya materi SPLDV dikarenakan pada materi tersebut, jika disajikan dalam bentuk soal cerita, 60\% siswa belum bisa mengerjakan.

Pada penelitian ini, koneksi matematis pada materi SPLDV dapat dijabarkan dalam beberapa indikator berikut:

1. Keterkaitan antara materi-materi yang telah dipelajari sebelumnya dengan materi SPLDV.

2. Keterkaitan antar konsep yang terdapat pada SPLDV

3. Keterkaitan antara jawaban yang didasarkan pada konsep. Keterkaitan antara SPLDV dengan kehidupan sehari-hari.

Penelitian tentang kemampuan koneksi matematis juga pernah dilakukan oleh Gustine Primadya Anandita (2015) yang menganalisis tentang "Analisis kemampuan koneksi matematis siswa SMP kelas VIII pada materi kubus dan balok" dan oleh Muhammad Romli (2016) yang berjudul "Profil koneksi matematis siswa perempuan SMA dengan kemampuan matematika tinggi dalam menyelesaikan masalah matematika"

\section{METODE PENELITIAN}

Jenis penelitian ini adalah pendekatan penelitian kualitatif. Menurut Creswell (2012:16), karakteristik penelitian kualitatif meliputi (1) mengeksplorasi suatu masalah dan mengembangkan pemahaman yang rinci dari fenomena pokok. (2) kajian pustaka berperan kecil, tetapi membenarkan masalah. (3) menyatakan tujuan dan pertanyaan penelitian secara umum dan luas sesuai dengan pengalaman subjek penelitian. (4) mengumpulkan data berdasarkan kata-kata dari sejumlah kecil individu sehingga pandangan subjek penelitian diperoleh. (5) menganalisis data untuk deskripsi dan tema menggunakan analisis teks dan mengintepretasikan makna yang lebih luas 
dari temuan. (6) menulis laporan menggunakan kriteria yang fleksibel, kriteria struktur yang muncul, dan kriteria evaluatif dan melibatkan refleksivitas subjektif dan bias peneliti.

Tujuan penelitian ini adalah untuk mendeskripsikan kemampuan koneksi matematis siswa pada materi Sistem Persamaan Linear Dua Variabel (SPLDV). Penelitian ini dilakukan pada salah satu SMP di kota Surabaya. Subjek penelitian ini adalah 3 siswa sekolah tersebut. Prosedur yang digunakan dalam penelitian ini terdiri dari tiga aspek, yaitu: aspek persiapan, pelaksanaan, dan analisis data. Pada aspek persiapan meliputi (1) kegiatan observasi untuk memperoleh data nilai ulangan harian siswa pada materi SPLDV dan menentukan jadwal penelitian. (2) menyusun desain penelitian. Desain ini mencakup pendahuluan, kajian teori, metode penelitian, dan rancangan instrumen penelitian. (3) melakukan diskusi bersama pembimbing terkait instrumen penelitian yang berupa soal tes kemampuan koneksi matematis dan rubrik penilaiannya. (4) melakukan revisi desain penelitian berdarkan saran pembimbing. Sedangkan aspek pelaksanaan meliputi, (1) memberikan tes koneksi matematis siswa pada materi SPLDV sebanyak 2 butir soal berdasarkan tiga aspek koneksi matematis yang meliputi koneksi matematis dalam satu topik yang sama, antara satu topik dengan topik yang lain, dan dalam kehidupan sehari-hari. (2) menganalisis jawaban siswa, (3) mengolah data yang diperoleh.

Menurut Natalia, dkk (2016), kriteria kemampuan koneksi matematis adalah sebagai berikut:

Tabel 1. Kriteria Kemampuan Koneksi Matematis

\begin{tabular}{lcc}
\hline Kriteria Kemampuan koneksi Matematis & skor & Kategori \\
\hline $\begin{array}{l}\text { Siswa mampu menjawab dan menjelaskan } \\
\text { koneksi ide-ide matematis secara lengkap dan } \\
\text { benar. }\end{array}$ & 4 & $\begin{array}{c}\text { Sangat Tinggi } \\
\text { (ST) }\end{array}$ \\
\hline $\begin{array}{l}\text { Siswa mampu menjawab koneksi seluruh ide-ide } \\
\text { matematis secara lengkap dan benar. }\end{array}$ & 3 & Tinggi (T) \\
\hline $\begin{array}{l}\text { Siswa mampu menjawab koneksi sebagian ide- } \\
\text { ide matematis dengan benar. }\end{array}$ & 2 & Cukup (C) \\
\hline $\begin{array}{l}\text { Siswa tidak mampu menjawab koneksi ide-ide } \\
\text { matematis dengan benar. }\end{array}$ & 1 & Rendah (R) \\
\hline $\begin{array}{l}\text { Siswa tidak menjawab soal koneksi ide-ide } \\
\text { matematis }\end{array}$ & 0 & $\begin{array}{c}\text { Sangat } \\
\text { Rendah (SR) }\end{array}$ \\
\hline
\end{tabular}

\section{HASIL DAN PEMBAHASAN}

Untuk mengetahui kemampuan koneksi matematis, disusun instrumen dengan 2 butir soal. Instrumen tersebut disusun mengacu pada kurikulum SMP kelas VIII semester ganjil dan mengacu pada tiga aspek koneksi matematis yang dikemukakan oleh NCTM. Meliputi: (1) masalah koneksi matematis dalam satu topik yang sama. (2) masalah koneksi matematis antara satu topik dengan topik matematika yang lain. (3) masalah koneksi matematis dalam konteks kehidupan sehari-hari. Adapun soal yang diberikan pada pelaksanaan tes untuk mengetahui bagaimana siswa mengkoneksikan ide-ide matematis pada materi SPLDV adalah sebagai berikut.

Sebuah pertandingan sepak bola antar kecamatan diselenggarakan di Stadion Lokajaya Tuban. Pihak penyelenggara menyediakan 500 lembar karcis yang terdiri dari karcis kelas ekonomi dan karcis kelas utama. Harga satu lembar karcis untuk kelas ekonomi adalah Rp. 6000,- dan untuk kelas utama adalah Rp. 8.000,-. 
Setelah pertandingan selesai, pihak panitia menghitung hasil penjualan. Total hasil penjualan dari karcis kelas ekonomi dan kelas utama adalah R. 3.360.000,- Berapakah jumlah karcis kelas ekonomi yang terjual?

Soal tersebut adalah soal untuk mengetahui kemampuan koneksi matematis dalam konteks kehidupan sehari-hari. Sedangkan hasil tes kemampuan koneksi matematis pada soal nomor 1 adalah sebagai berikut:

Tabel 2. Hasil Kemampuan Koneksi Matematis

\begin{tabular}{|c|c|c|c|c|c|c|c|}
\hline \multirow{2}{*}{ No } & \multirow{2}{*}{ Nama siswa } & \multicolumn{4}{|c|}{ Kriteria Penilaian soal 1} & \multirow{2}{*}{ Skor } & \multirow{2}{*}{ Kategori } \\
\hline & & KM 1 & KM 2 & KM 3 & KM 4 & & \\
\hline 1. & S-1 & 1 & 1 & 1 & 0 & 3 & Tinggi \\
\hline 2. & S-2 & 1 & 1 & 0 & 0 & 2 & Cukup \\
\hline 3. & S-3 & 1 & 1 & 0 & 0 & 2 & Cukup \\
\hline
\end{tabular}

Keterangan:

KM 1: mendeskripsikan apa yang diketahui dan yang ditanyakan.

KM 2: menggunakan metode eliminasi, subtitusi, atau campuran untuk menghitung jumlah karcis kelas ekonomi.

KM 3: menentukan jumlah karcis kelas ekonomi yang terjual.

KM 4: menjelaskan hubungan konsep SPLDV pada masalah kehidupan sehari-hari.

Berdasarkan data hasil tes kemampuan koneksi, ada satu siswa yang memperoleh skor 3. Hal ini berarti siswa tersebut hanya dapat menerapkan ide-ide matematis SPLDV yaitu mendeskripsikan apa yang diketahui dan yang ditanyakan sesuai dengan ilustrasi soal, kemudian menghitung jumlah karcis kelas ekonomi yang terjual dengan menggunakan metode yang digunakan pada SPLDV (metode subtitusi, eliminasi, atau campuran). Namun, siswa tersebut tidak dapat menjelaskan alasan pada setiap langkah penyelesaiannya dan tidak dapat menjelaskan hubungan materi tersebut terhadap masalah kehidupan sehari-hari. Jadi, koneksi matematis siswa tersebut berada pada kategori "tinggi".

Selain itu, ada dua siswa yang memperoleh skor 2. Hal ini dikarenakan siswa hanya bisa menerapkan ide-ide matematis SPLDV yaitu mendeskripsikan apa yang diketahui dan yang ditanyakan sesuai dengan ilustrasi soal dan menghitung jumlah karcis kelas ekonomi dengan menggunakan metode yang telah digunakan pada SPLDV. Namun, pada saat menentukan jumlah karcis kelas ekonomi siswa tersebut kurang teliti sehingga hasilnya kurang benar. Disamping itu, siswa tidak dapat menjelaskan hubungan materi tersebut terhadap masalah kehidupan sehari-hari. Sehingga, koneksi matematis siswa tersebut berada pada kategori "cukup"..

Adapun soal tes yang diberikan untuk mengetahui bagaimana siswa mengkoneksikan ideide matematis pada materi SPLDV dengan materi persamaan garis lurus adalah sebagai berikut: Diketahui sebuah sistem persamaan $\left\{\begin{array}{c}2 x+3 y=12 \\ 4 x-3 y-6=0\end{array}\right.$, Tentukan himpunan selesainya dengan menggunakan metode grafik!

Sedangkan hasil tes kemampuan koneksi matematis pada soal tersebut adalah sebagai berikut: 
Tabel 3. Hasil Tes Kemampuan Koneksi Matematis

\begin{tabular}{cccllllll}
\hline \multirow{2}{*}{ No } & \multirow{2}{*}{ Nama siswa } & \multicolumn{4}{c}{ Kriteria Penilaian soal 1 } & \multirow{2}{*}{ Skor } & \multirow{2}{*}{ Kategori } \\
\cline { 3 - 6 } & & KM 1 & KM 2 & KM 3 & KM 4 & & \\
\hline 1. & S-1 & 1 & 1 & 1 & 0 & 3 & Tinggi \\
\hline 2. & s-2 & 1 & 1 & 0 & 0 & 2 & Cukup \\
\hline 3. & S-3 & 1 & 1 & 0 & 0 & 2 & Cukup \\
\hline
\end{tabular}

Keterangan:

KM 1: mendeskripsikan apa yang diketahui dan yang ditanyakan.

KM 2: $\quad$ menggunakan metode grafik untuk menyelesaikannya.

KM 3: menentukan himpunan selesainya berdasarkan metode grafik.

KM 4: menjelaskan kembali apa yang telah dikerjakan oleh siswa.

Berdasarkan data hasil tes kemampuan koneksi, ada satu siswa yang memperoleh skor 3. Hal ini berarti siswa hanya dapat menerapkan ide-ide matematis SPLDV yaitu mendeskripsikan apa yang diketahui dan yang ditanyakan sesuai dengan ilustrasi soal. Kemudian menyelesaikannya dengan metode grafik. Namun, siswa tersebut kurang bisa menjelaskan alasan pada setiap langkah peneyelsaiannya atau kurang bisa dalam menjelaskan kembali apa yang telah ditulis dalam lembar jawaban. Jadi, koneksi matematis siswa tersebut berada pada kategori "tinggi"

Demikian halnya dengan soal nomor satu yang berkaitan dengan kehidupan sehari-hari. Ada dua siswa memperoleh skor 2. Hal ini dikarenakan karena siswa hanya bisa menerapkan ide-ide matematis SPLDV yaitu mendeskripsikan apa yang diketahui dan ditanyakan sesuai dengan ilustrasi soal. Namun dalam pengerjaannya, kedua siswa tersebut kurang teliti dan kurang faham dengan apa yang dikerjakan. Disamping itu, siswa juga tidak dapat menjelaskan kembali apa yang telah dikerjakan. Sehingga, koneksi matematis siswa tersebut berada pada kategori "cukup".

\section{SIMPULAN}

Kemampuan koneksi dalam matematika memegang peran penting dalam menyelesaikan masalah matematika. Dengan kemampuan tersebut, siswa dapat memahami masalah matematika secara detail. Namun, dalam tes kemampuan koneksi yang dilakukan oleh 3 siswa. Hanya 1 siswa yang koneksi matematisnya berada pada kategori tinggi. Sedangkan 2 siswa yang lain berada pada kategori cukup. Hal ini dikarenakan ketiga siswa tersebut kesulitan dalam menjelasakan apa yaang telah dia kerjakan atau dengan kata lain, mereka masih sulit untuk menjelaskan alasan pada setiap langkah penyelesaiannya

\section{DAFTAR PUSTAKA}

Ruspiani, 2000. Kemampuan siswa dalam melakukan koneksi matematika. Tesis Jurusan Matematika UPI Bandung.

NCTM. 2000. Principle and Standards for School Mathematics. Reston,VA:NCTM

Mahmudah, Y. F. 2013. Kemampuan Koneksi Matematis Siswa Kelas VIII pada Materi Persamaan Garis. Tesis tidak diterbitkan. Malang: Pps UM.

Warih, P.D, Parta, I.N. \& Rahardjo, S. 2016. Analisis Kemampuan Koneksi Matematis Siswa Kelas VIII pada Materi Teorema Phytagoras. Makalah disajikan dalam Konferensi Nasional Penelitian Matematika dan Pembelajarannya (KNPMP I) Universitas Muhammadiyah, Surakarta, 12 Maret 
Anandita. G, 2015. Analisis kemampuan koneksi matematis siswa SMP kelas VIII pada materi kubus dan balok. Skripsi jurusan Matematika Universitas Negeri Semarang

Creswell, J., W., 2012, Research design Pendekatan kualitatif, Kuantitatif dan Mixed; Cetakan ke-2, Yogyakarta: Pustaka Pelajar.

Natalia, dkk. 2016, Kemampuan koneksi matematis siswa kelas X materi perbandingan trigonometri; Prosiding seminar nasional pendidikan matematika Universitas Negeri Malang 